\title{
The preventive effect of $\beta_{3}$ adrenoceptor stimulation against experimentally induced reflux esophagitis
}

\author{
HA Malek, A Shalaby \\ Clinical Pharmacology Department, Mansoura University, Faculty of Medicine, Mansoura, Egypt
}

Received: May 4, 2014

Accepted after revision: August 22, 2014

\begin{abstract}
$\mathrm{A} \beta_{3}$ adrenoceptor agonist plays an important regulatory role in stimulation of thermogenesis and lipolysis and it appears to have anti-ulcer and spasmolytic effects. So the present aim was to examine the effect of BRL 37344 (a selective $\mathrm{B}_{3}$ adrenoceptor agonist) on reflux esophagitis. Methods: Forty-eight rats were divided into twelve shamoperated rats and thirty-six rats with induced reflux esophagitis (RE), which were divided into either RE alone or pretreated with BRL 37344 and/or omeprazole with or without indomethacin. RE was induced in rats, then gastric acid output, $\mathrm{pH}$, plasma nitric oxide (NO), esophageal $\mathrm{PGE}_{2}$, malondialdehyde (MDA) and reduced glutathione (GSH) were measured and the esophageal injury was assessed by macroscopic damage score. Results: Pretreatment with BRL significantly increased plasma NO, GSH, decreased acid output, esophageal MDA and esophageal injury in comparison to pretreatment. In addition, there was a no significant increase in esophageal $\mathrm{PGE}_{2}$. Conclusion: It can be concluded that BRL 37344 has an anti-oxidant protective effect in rats with RE.
\end{abstract}

Keywords: reflux esophagitis, $\beta_{3}$ receptors, BRL 37344, anti-oxidant effect, rat model

Reflux esophagitis is a disease where gastric juices reach the esophagus because of a transient lower esophageal sphincter (LES) relaxation, a low esophageal clearance speed, and a lack of mucosal resistance (7). Reflux of gastric contents leads to inflammation, ulceration, and destruction of the esophagus squamous epithelium $(3,12)$. This could lead to deleterious pathological conditions, as chronic esophagitis, aspiration pneumonia, esophageal strictures, and even malignancy in form of Barrett's esophagus (8).

The severity of reflux esophagitis does not only depend on acid reflux, the impaired mucosal resistance is also involved (21). Some studies suggested that oxygen derived free radicals in RE induced esophageal mucosal damage leading to mucosal inflammation, and the management of these free radicals role and the inflammatory responses associated with, may be a potential therapeutic effect in the management of RE (19).

The neural and paracrine systems [cyclooxygenase-prostaglandin (COX-PG)] and nitric oxide synthase (NO) are involved in the maintenance of the integrity of epithelial barrier of the GIT against aggressive factors (17).

Different receptors are responsible for norepinephrine and epinephrine effects, one of them is the $\beta_{3}$ adrenergic receptor. $B_{3}$ receptors are present in a variety of tissues as brain, adipose tissues, stomach, and urinary bladder (11). Beta stimulation produces a delay in gastric emptying. In guinea pigs, it induces a cAMP-dependent relaxation of stomach fundus (13). In rats, $\beta_{3}$ adrenoceptors produce a reduction in acidic secretion due to pentagastrine stimulation (1).

Corresponding author: Hala Abdel Malak, Associate Prof. of Clinical Pharmacology

Clinical Pharmacology Department, Mansoura University, Mansoura, Egypt

Fax:+20 (50) 2223613-124; E-mail: halamalek@live.com 
The antiulcer action of $\beta_{3}$-adrenoceptor agonists is mediated by a decrease in gastric acid secretion, an enhancement of mucin activity and antioxidant effect in the gastro-duodenal region (25).

Proton pump inhibitor, omeprazole is the standard therapeutic drug in acid-related disorders as gastro-esophageal reflux disease, Zollinger-Ellison syndrome, and peptic-ulcer disease (14). Omeprazole inhibits gastric acid secretion to control the previous disorders (27).

The aim of this work was to study the potential biochemical effects of BRL 37344, as compared with omeprazole on a rat model of reflux esophagitis.

\section{Materials and Methods}

\section{Animals}

Forty-eight Sprague-Dawley rats (250-300 g) were housed in standard cages in groups of six animals per cage under controlled conditions (temperature $25 \pm 10^{\circ} \mathrm{C}$, and a $12: 12 \mathrm{light} / \mathrm{dark}$ cycle), with free access to food and water for 1 week for acclimatization. They were fasted for $24 \mathrm{~h}$ before the experiment. Drinking water was freely available to the animals up to 2 hours before the experiment. All procedures were approved by the Medical Research, Ethical Committee, Mansoura University, Mansoura, Egypt.

\section{Esophagitis induction}

Under ether inhalation anesthesia, the abdomen was incised along the midline and then both the pylorus and the junction between the fore stomach and corpus were simultaneously ligated according to the method of Nakamura (23). So, the capacity of the stomach to preserve the gastric juice was decreased, resulting in gastric juice reflux into the esophagus, a longitudinal cardiomyotomy $1 \mathrm{~cm}$ of length was performed across the gastro-esophageal junction to enhance reflux. The animals were fasted for $36 \mathrm{~h}$ after the operation but were allowed to tap water ad libitum. Then, after 36 hours, they were sacrificed with an overdose of ether, and the esophagus and stomach was removed as one unit.

\section{Animal groups}

Forty-eight rats were divided into the following groups:

- Group one (12 rats): It was included sham-operated rats (control group).

These rats were further subdivided into:

1a (six rats): sham-operated rats.

$1 \mathrm{~b}$ (six rats): sham-operated rats pretreated with indomethacin.

- Group two (12 rats): Rats in which reflux esophagitis was induced. These rats were further subdivided into:

$2 \mathrm{a}$ (six rats): Rats with reflux esophagitis alone.

$2 \mathrm{~b}$ (six rats): Rats with reflux esophagitis were induced + they received indomethacin intraperitoneally ( $5 \mathrm{mg} / \mathrm{kg}$, Nile Parma, Egypt) was given 30 minutes before the start of ligation (17).

- Group three (12 rats): BRL 37344 sodium salt powder (Sigma, USA) dissolved in distilled water was given to rats before induction of reflux esophagitis. These rats were further subdivided into: 
3a (six rats): BRL 37344 (1 mg/kg, orally) was given to rats 30 minutes before induction of reflux esophagitis (6).

3b (six rats): BRL 37344 was given before induction of reflux esophagitis in indomethacin treated rats. Rats received BRL 37344 (1 mg/kg orally) followed 30 minutes later by indomethacin ( $5 \mathrm{mg} / \mathrm{kg}$ intraperitoneally) and finally 30 minutes later by induction of reflux esophagitis.

- Group four (12 rats): Omeprazole (EIPICO, Egypt) was also dissolved in distilled water and given to rats before induction of reflux esophagitis. These rats were further subdivided into:

4a (six rats): Omeprazole (60 mg/kg, orally) (24) was given to rats 30 minutes before induction of reflux esophagitis.

4b (six rats): Omeprazole was given before induction of reflux esophagitis in indomethacin treated rats. Rats received omeprazole $(60 \mathrm{mg} / \mathrm{kg}$ orally) followed 30 minutes later by indomethacin ( $5 \mathrm{mg} / \mathrm{kg}$ intraperitoneally) and finally 30 minutes later by induction of reflux esophagitis.

\section{Quantification of gastric acid secretion}

After sacrification, gastric contents were collected and centrifuged at $3000 \mathrm{~g}$ for $10 \mathrm{~min}$ at $4{ }^{\circ} \mathrm{C}$. After centrifugation, the supernatant gastric juice volumes $(\mathrm{ml} / \mathrm{rat}), \mathrm{pH}$ values $(\mathrm{pH}$ meter, Cyber Scan 500) $(\mu \mathrm{Eq} / 1)$ were measured. Acidities were determined by titration of gastric juice vs. $0.1 \mathrm{~N} \mathrm{NaOH}$ to $\mathrm{pH} 7.0$ and total acid outputs are expressed as $\mu \mathrm{Eq} / \mathrm{h}$ (24).

\section{Determination of plasma nitric oxide (NO) level}

A venous blood sample was withdrawn from rat tail veins into EDTA containing vials and centrifuged, for determination of $\mathrm{NO}$ concentration with QuantiChro ${ }^{\mathrm{M}}$ Nitric oxide Assay Kit (DINO-250) (Bioassay Systems, USA).

\section{Biochemical assays of the esophageal mucosa}

The esophageal mucosa was stripped of the muscle layer, and stored frozen at $-70{ }^{\circ} \mathrm{C}$ for biochemical assays. Malondialdehyde (MDA) was determined in esophageal mucosa according to the method of Buege and Aust (10) colorimetrically.

GSH level was calorimetrically measured with Bioassay Systems' QuantiChro ${ }^{\mathrm{M}}$ Glutathione Assay Kit (DIGT-250) (Bioassay Systems, USA) according to the manufacturer's instructions.

Esophageal mucosal $\mathrm{PGE}_{2}$ concentration was determined using an immunoassay kit (R \& D System, Inc., Minneapolis MN, USA).

\section{Measurement of gross esophageal lesion}

The esophagi were resected up to the upper segment close to the hypo pharynx. Then, they were cut along with the longitudinal axis. The lesion length $(\mathrm{mm})$ that had developed in the esophagus was measured from the ruler using hand lens.

For examination of the macroscopic changes, the esophageal lesion score system was used from 0 to 3 and photographed. According to this macroscopic scoring, esophagus had score 0 for normal shimmering mucosa, 1 for hyperemic or edematous mucosa with focal hemorrhagic spots, 2 for multiple erosions with hematin attached, 3 for ulcerations and dark necrotic spots (17). 


\section{Analysis of data}

All data were compared by ANOVA followed by post hoc Tukey's test, except the scoring method was determined by Kruskal-Wallis test followed by a Mann-Whitney test. The values were expressed as means $\pm \mathrm{SD}$. A $p$ value of $\leq 0.05$ was considered statistically significant. The statistical analysis was performed using the SPSS statistical Package version 17.0 (SPSS, Chicago, IL, USA).

\section{Results}

Effects of BRL 37344, omeprazole on biochemical, macroscopic parameters in rats with induced reflux esophagitis (Table I):

Table I. Effects of BRL 37344 and omeprazole on biochemical parameters and macroscopic score in rats with induced reflux esophagitis (Mean $\pm \mathrm{SD})(n=6)$

\begin{tabular}{|l|c|c|c|c|}
\hline & Group 1a & Group 2a & Group 3a & Group 4a \\
\hline Acid output $(\mu \mathrm{Eq} / \mathrm{h})$ & $22.30 \pm 1.2$ & $216.83 \pm 5.19^{\mathrm{a}}$ & $153.66 \pm 1.86^{\mathrm{abc}}$ & $85.83 \pm 1.83^{\mathrm{ab}}$ \\
\hline $\mathrm{PH}$ & $7.36 \pm 0.19$ & $1.46 \pm 0.13^{\mathrm{a}}$ & $3.68 \pm 0.14^{\mathrm{abc}}$ & $5.46 \pm 0.25^{\mathrm{ab}}$ \\
\hline Nitric oxide $(\mu \mathrm{mol} / \mathrm{L})$ & $27.83 \pm 1.16$ & $37.50 \pm 1.04^{\mathrm{a}}$ & $46.50 \pm 1.04^{\mathrm{abc}}$ & $37.50 \pm 1.04^{\mathrm{a}}$ \\
\hline PGE $2(\mathrm{ng} / \mathrm{g}$ tissue $)$ & $133.16 \pm 1.47$ & $243.33 \pm 1.86^{\mathrm{a}}$ & $247.32 \pm 1.36^{\mathrm{a}}$ & $244.33 \pm 1.50^{\mathrm{a}}$ \\
\hline MDA $(\mu \mathrm{M} / \mathrm{g}$ tissue $)$ & $0.40 \pm 0.08$ & $3.56 \pm 0.10^{\mathrm{a}}$ & $1.16 \pm 0.12^{\mathrm{ab}}$ & $1.50 \pm 0.14^{\mathrm{ab}}$ \\
\hline GSH $(\mu \mathrm{M} / \mathrm{g}$ tissue $)$ & $184.33 \pm 2.5$ & $33 \pm 0.89^{\mathrm{a}}$ & $142.83 \pm 2.13^{\mathrm{ab}}$ & $145.50 \pm 1.87^{\mathrm{ab}}$ \\
\hline Damage score & - & $2.56 \pm 0.18^{\mathrm{a}}$ & $1.50 \pm 0.54^{\mathrm{ab}}$ & $1.33 \pm 0.51^{\mathrm{ab}}$ \\
\hline Lesion length $(\mathrm{mm})$ & - & $43.33 \pm 2.16^{\mathrm{a}}$ & $12.50 \pm 1.51^{\mathrm{abc}}$ & $22.33 \pm 1.86^{\mathrm{ab}}$ \\
\hline
\end{tabular}

${ }^{\mathrm{a}}$ versus group $1 \mathrm{a},{ }^{\mathrm{b}}$ versus group $2 \mathrm{a},{ }^{\mathrm{c}}$ versus group $4 \mathrm{a}$ $p<0.05$ was statistically significant

In RE group, gastric acid output, plasma nitric oxide (NO), mucosal $\mathrm{PGE}_{2}$ and MDA increased while $\mathrm{pH}, \mathrm{GSH}$ decreased significantly, relative to sham-operated rats (Figs 1 and 2). Rats with RE had a significant macroscopic damage score of $2.66 \pm 0.81$ and lesion length $43.33 \pm 2.16 \mathrm{~mm}(p \leq 0.05)$ (Figs 3 and 4$)$, relative to sham-operated rats.

BRL 37344 group, showed a significant decrease in acid output, MDA, while a significant increase in $\mathrm{pH}$, plasma NO, and GSH $(p \leq 0.05)$, with no significant effect $(p \geq 0.05)$ was shown on mucosal $\mathrm{PGE}_{2}$ relative to the RE group (Figs 1 and 2). In addition, there was a significant decrease in the macroscopic damage score, and lesion length (Figs 3 and 4).

Omeprazole group, showed a significant decrease in acid output, and MDA, increased $\mathrm{pH}$ and GSH, while no significant effect was shown on plasma $\mathrm{NO}$ and mucosal $\mathrm{PGE}_{2}(p \geq$ 0.05 ) relative to the RE group (Figs 1 and 2). Moreover, it decreased significantly the macroscopic damage score, and lesion length relative to the RE group (Figs 3 and 4).

Effects of BRL 37344, omeprazole on biochemical and macroscopic changes in indomethacin treated rats with induced reflux esophagitis (Table II). 
Table II. Effects of BRL 37344 and omeprazole on biochemical parameters and macroscopic score in indomethacin treated rats with induced reflux esophagitis (Mean $\pm \mathrm{SD})(n=6)$

\begin{tabular}{|l|c|c|c|c|}
\hline & Group 1b & Group 2b & Group 3b & Group 4b \\
\hline Acid output $(\mu \mathrm{Eq} / \mathrm{h})$ & $23.66 \pm 1.36$ & $245.50 \pm 1.51^{\mathrm{a}}$ & $146.83 \pm 7.08^{\mathrm{abc}}$ & $96.83 \pm 1.94^{\mathrm{ab}}$ \\
\hline PH & $6.35 \pm 0.74$ & $1.23 \pm 0.10^{\mathrm{a}}$ & $3.48 \pm 0.27^{\mathrm{abc}}$ & $4.33 \pm 0.81^{\mathrm{ab}}$ \\
\hline Nitric oxide $(\mu \mathrm{mol} / \mathrm{L})$ & $26.83 \pm 1.16$ & $21.83 \pm 1.47^{\mathrm{a}}$ & $27.66 \pm 0.81^{\mathrm{b}}$ & $22.66 \pm 1.63^{\mathrm{a}}$ \\
\hline PGE $(\mathrm{ng} / \mathrm{g}$ tissue $)$ & $134.16 \pm 2.48$ & $84.83 \pm 2.63^{\mathrm{a}}$ & $92.16 \pm 1.94^{\mathrm{a}}$ & $85 \pm 0.89^{\mathrm{a}}$ \\
\hline MDA $(\mu \mathrm{M} / \mathrm{g}$ tissue $)$ & $0.33 \pm 0.12$ & $3.48 \pm 0.24^{\mathrm{a}}$ & $0.80 \pm 0.08^{\mathrm{ab}}$ & $0.81 \pm 0.09^{\mathrm{ab}}$ \\
\hline GSH $(\mu \mathrm{M} / \mathrm{g}$ tissue $)$ & $185.83 \pm 3.06$ & $34.33 \pm 1.63^{\mathrm{a}}$ & $143.66 \pm 2.16^{\mathrm{abc}}$ & $137 \pm 1.41^{\mathrm{ab}}$ \\
\hline Damage score & - & $2.66 \pm 0.81^{\mathrm{a}}$ & $0.43 \pm 0.10^{\mathrm{abc}}$ & $0.80 \pm 0.08^{\mathrm{ab}}$ \\
\hline Lesion length $(\mathrm{mm})$ & - & $45.53 \pm 1.55^{\mathrm{a}}$ & $13.56 \pm 0.38^{\mathrm{abc}}$ & $21.83 \pm 1.47^{\mathrm{ab}}$ \\
\hline
\end{tabular}

${ }^{\mathrm{a}}$ versus group $1 \mathrm{~b},{ }^{\mathrm{b}}$ versus group $2 \mathrm{~b},{ }^{\mathrm{c}}$ versus group $3 \mathrm{~b}$ $p<0.05$ was statistically significant

The RE experiments, in indomethacin-treated rats, gastric acid output, and MDA increased while $\mathrm{pH}$, plasma $\mathrm{NO}, \mathrm{GSH}$ and mucosal $\mathrm{PGE}_{2}$ decreased significantly relative to sham-operated rats $(p \leq 0.05)$ (Figs 4 and 5). Indomethacin-treated rats with induced RE had a significant macroscopic damage score of $2.56 \pm 0.18$ (Fig. 5) and lesion length $45.53 \pm$ $1.55 \mathrm{~mm}(p \leq 0.05)$ (Fig. 6), relative to sham-operated rats.

BRL 37344 administration before induction of RE in indomethacin-treated rats significantly reduced acid output and MDA and it increased $\mathrm{pH}, \mathrm{NO}$ and GSH $(p \leq 0.05)$ relative to the RE group (Figs 4 and 5). There was no significant increase in $\operatorname{PGE}_{2}(p \geq 0.05)$ (Fig. 4). Moreover, it significantly decreased the macroscopic damage score and lesion length relative to the RE group ( $p \leq 0.05$ ) (Fig. 4).

Omeprazole administration before induction of $\mathrm{RE}$ in the indomethacin group significantly decreased acid output and MDA, while it increased $\mathrm{pH}$ and GSH $(p \leq 0.05)$ (Figs 4 and 5). No significant effect was shown on neither on NO levels or mucosal $\mathrm{PGE}_{2}(p \geq$ 0.05 ) relative to the RE group (Fig. 4). It also significantly reduced the macroscopic damage score, lesion length relative to the RE group $(p \leq 0.05)$ (Figs 5 and 6$)$.

\section{Discussion}

$\mathrm{RE}$ is likely to be associated with impairment of different mechanisms as, endogenous NO release after an initial increment under gastric juice effect, cytokine expression and release of adhesion molecules (26). The calcium dependent neuronal nitric oxide synthase (nNOS) plays a physiological role in the gastrointestinal motility. Its dysfunction can lead to motility and lower esophageal sphincter disorders (22). Moreover, production of NO by endothelial nitric oxide synthase (eNOS) inhibits leucocytes aggregation and it is essential for the maintenance of esophageal mucosal blood flow. Oxygen free radicals are also implicated in the pathogenesis of reflux esophagitis $(17,18,33)$.

This work evaluated the biochemical effects of the antiulcer drug BRL 37344, on reflux esophagitis with and without indomethacin administration. 


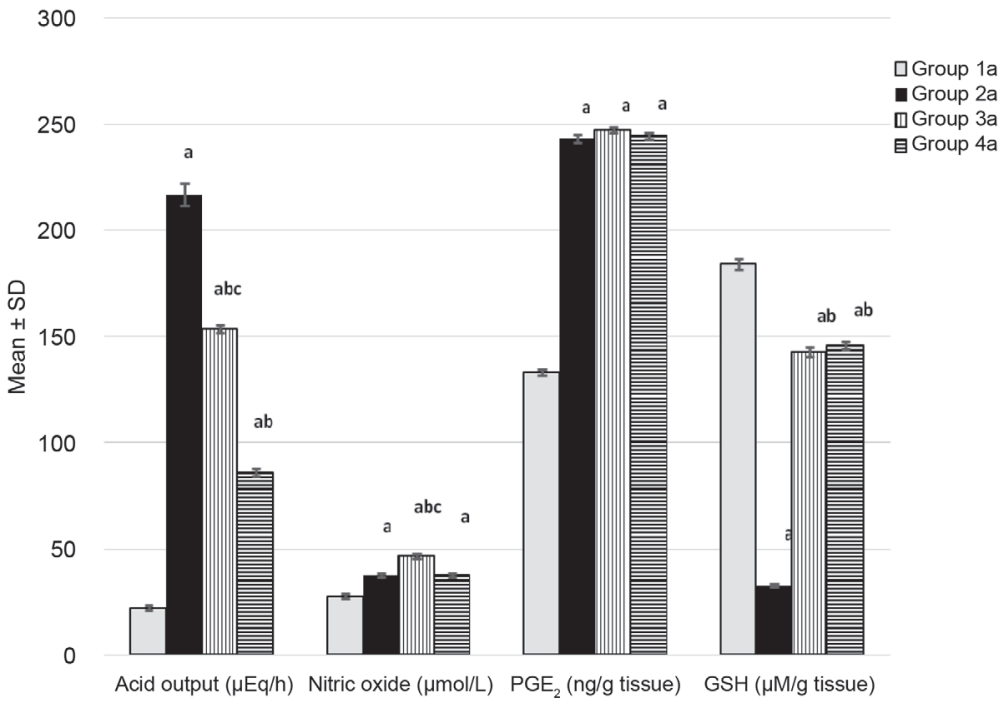

Fig. 1. Effects of BRL 37344 and omeprazole on biochemical parameters in rats with induced reflux esophagitis $($ Mean $\pm \mathrm{SD})(n=6)$

${ }^{\mathrm{a}}$ versus group 1a, ${ }^{\mathrm{b}}$ versus group $2 \mathrm{a},{ }^{\mathrm{c}}$ versus group $4 \mathrm{a}$ $p \leq 0.05$ was statistically significant

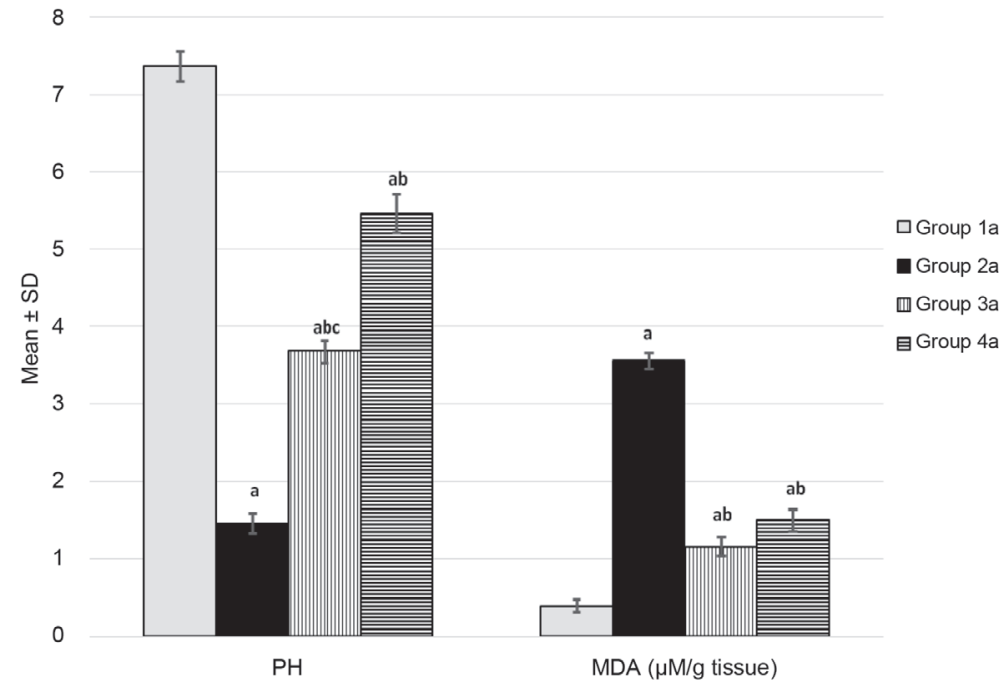

Fig. 2. Effects of BRL 37344 and omeprazole on PH and MDA in rats with induced reflux esophagitis

$$
(\text { Mean } \pm \mathrm{SD})(n=6)
$$

${ }^{\mathrm{a}}$ versus group 1a, ${ }^{\mathrm{b}}$ versus group $2 \mathrm{a},{ }^{\mathrm{c}}$ versus group $4 \mathrm{a}$ $p \leq 0.05$ was statistically significant 


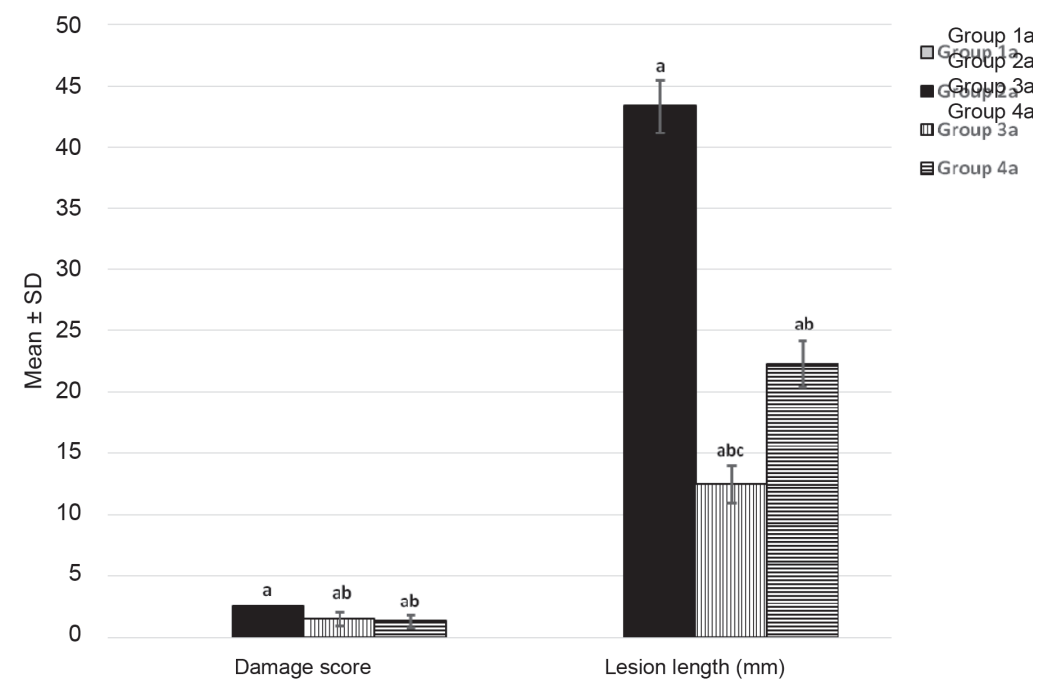

Fig. 3. Effects of BRL 37344 and omeprazole on macroscopic score in rats with induced reflux esophagitis $($ Mean $\pm \mathrm{SD})(n=6)$

${ }^{\mathrm{a}}$ versus group 1a, ${ }^{\mathrm{b}}$ versus group $2 \mathrm{a},{ }^{\mathrm{c}}$ versus group $4 \mathrm{a}$ $p \leq 0.05$ was statistically significant

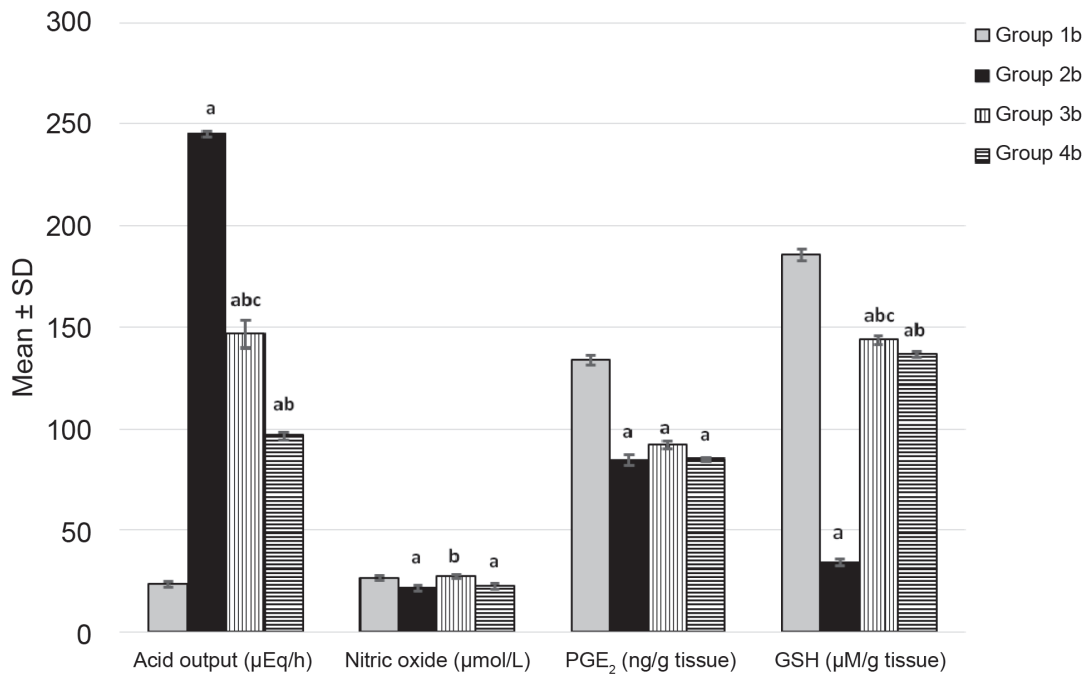

Fig. 4. Effects of BRL 37344 and omeprazole on biochemical parameters in indomethacin-treated rats with induced reflux esophagitis (Mean $\pm \mathrm{SD})(n=6)$

${ }^{\mathrm{a}}$ versus group $1 \mathrm{~b},{ }^{\mathrm{b}}$ versus group $2 \mathrm{~b},{ }^{\mathrm{c}}$ versus group $3 \mathrm{~b}$ $p \leq 0.05$ was statistically significant 


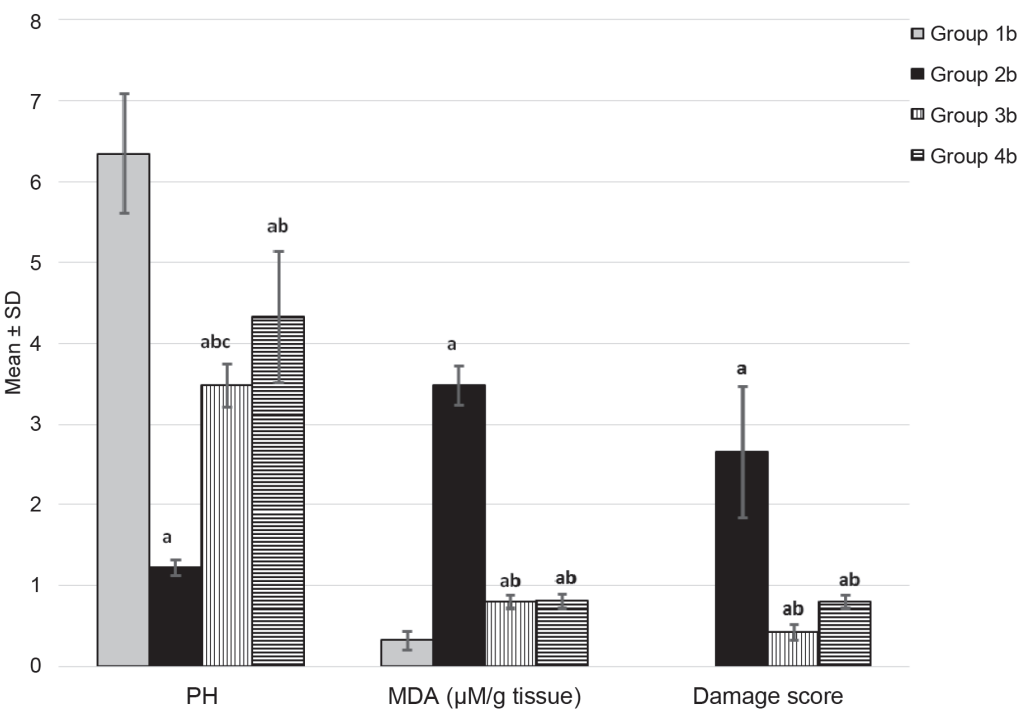

Fig. 5. Effects of BRL 37344 and omeprazole on PH, MDA and damage score in indomethacin-treated rats with induced reflux esophagitis (Mean $\pm \mathrm{SD})(n=6)$

${ }^{\mathrm{a}}$ versus group $1 \mathrm{~b},{ }^{\mathrm{b}}$ versus group $2 \mathrm{~b},{ }^{\mathrm{c}}$ versus group $3 \mathrm{~b}$ $p \leq 0.05$ was statistically significant

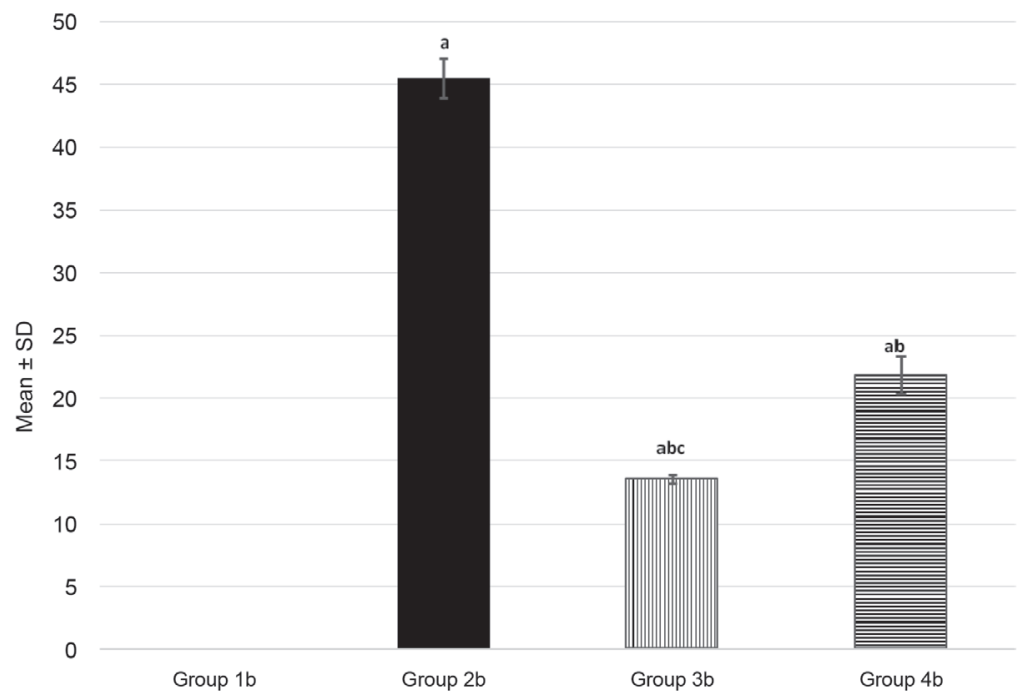

Fig. 6. Effect of BRL 37344 and omeprazole on lesion length $(\mathrm{mm})$ in indomethacin-treated rats with induced reflux esophagitis (Mean $\pm \mathrm{SD})(n=6)$

${ }^{\mathrm{a}}$ versus group $1 \mathrm{~b},{ }^{\mathrm{b}}$ versus group $2 \mathrm{~b},{ }^{\mathrm{c}}$ versus group $3 \mathrm{~b}$ $p \leq 0.05$ was statistically significant 
Acute RE caused a significant increase in gastric acid output that resulted in a compensatory increase in plasma $\mathrm{NO}$ and $\mathrm{PGE}_{2}$ generation. This was associated with a decrease in $\mathrm{pH}$. On the other hand, indomethacin a non-selective blocker of cyclooxygenaseprostaglandin $(\mathrm{COX} / \mathrm{PG})$ system caused a dramatic suppression of $\mathrm{PG}$ and NO. This was associated with a significant increase in gastric acid output, decrease in $\mathrm{pH}$.

The present results revealed that BRL 37344 administration, before induction of RE in rats with or without indomethacin, significantly decreased acid output, and increased $\mathrm{pH}$. The role of NO was examined by Kato et al. (15) who have stated that NO reduces gastric acid secretion in basal and stimulated conditions. While Paul et al. (25) have also reported that a $\beta 3$ agonist ZD 7114 and other agonists through $\beta 3$ receptors, decrease gastric acid secretion, and they offer an esophagus protective activity against GERD via stimulation of the contractile activity of the lower esophageal sphincter leading to attenuation of the gastro-esophageal reflux $(2,29)$.

BRL 37344 also have shown a significant decrease in esophageal lipid peroxidation products (MDA) that were increased by RE, whereas, the depleted anti-oxidant glutathione observed in RE were replenished by its free radical scavenging and antioxidant effects, resulting in the improvement of esophageal defense mechanism.

Barbier et al. (6) have reported that BRL 37344 has strong anti-inflammatory effect as it inhibits the expression of the proinflammatory cytokine TNF alpha in colitis.

Vasina et al. (31) have found that $\beta 3$ agonists protect the gastrointestinal mucosa from oxidative damage and inflammation caused by TNF-alpha induced reactive oxygen species (ROS). Both CL 316234 and BRL 37344 produce an inhibitory effect on indomethacin induced antral gastric ulceration in a rat model of peptic ulcer and proposed a possible vaso dilator action of these drugs involved in their gastric mucosal protection (4).

Kato et al. (15) have found that BRL 37344 plays a protective, antistress role in the gastric mucosa via its vasodilator action and smooth muscle relaxant-like effect. $\beta_{3}$ agonists stimulate bicarbonate secretion in the stomach and duodenum and have a role in repairing their ulcers (25).

Omeprazole administration significantly improved the pathogenesis and the biochemical changes of RE. Gastric acid secretion inhibition by proton pump inhibitors (PPI) as omeprazole is a vital step to control the RE disorder (28). They irreversible inhibit the $\mathrm{H}^{+}-\mathrm{K}^{+}-$ ATPase, the terminal proton pump of the parietal cell (27). They are converted to thiopHilicsulfenamide that reacts with the Cys-813 residue in the catalytic subunit of the $\mathrm{H}^{+}-\mathrm{K}^{+}$-ATPase, involved in enzyme inactivation (34).

Omeprazole plays a significant role in gastro protection by acting as a potent antioxidant and antiapoptotic molecule besides to the antisecretory action, and thus enhancing the ulcer healing process (9).

Suzuki et al. (30) have demonstrated that omeprazole, in vitro, modulates neutrophil function through inhibition of oxygen derived free radical synthesis and glucuronidase degradation. On the other hand, omeprazole still causes (and the other conventional antiulcer drugs) many adverse effects and drug-drug interactions. These harmful effects may be the trigger point for looking for an alternative therapy $(5,9,16,19,20,32)$.

\section{Conclusion}

BRL 37344 (a selective $\beta 3$ adrenoceptor agonist) has a protective effect on GERD through antioxidant-like effect which in turn decreases esophageal damage. 


\section{Conflict of interest}

There is no conflict of interest and both authors performed the work.

\section{REFERENCES}

1. Adami M, Coruzzi G, Sotirov E, Bertini S, Soldani G: Pharmacological evidence for $\beta_{3}$ adrenoceptors in the control of rat gastric acid secretion. Dig. Dis. Sci. 48(2), 334-339 (2003)

2. Arch JR, Kaumann AJ: Beta 3 and atypical beta adrenoceptors. Med. Res. Rev. 13(6), 663-729 (1993)

3. Aste H, Bonelli L, Ferraris R, Conio M, Lapertosa G: Gastrooesophageal reflux disease; Relationship between clinical and histological features. Dig. Dis. Sci. 44(12), 2412-2418 (1999)

4. Bahl AK, Clayton NM, Coates J, Martin DP, Oakley IG, Strong P, Trevethick MA: Comparison of the profiles of agonists as stimulants of the beta 3-adrenoceptor in vitro with their gastroprotective effects in the conscious rat. Br. J. Pharmacol. 117(3), 580-586 (1996)

5. Bandyopadhyay D, Bandyopadhyay A, Das PK, Reiter RJ: Melatonin protects against gastric ulceration and increases the efficacy of ranitidine and omeprazole in reducing gastric damage. J. Pineal. Res. 33(1), 1-7 (2002)

6. Barbier M, Attoub S, Joubert M, Bado A, Laboisse C, Cherbut C, Galmiche J: Proinflammatory role of leptin in experimental colitis in rats: Benefit of cholecystokinin-B antagonist and B 3-agonist. Life Sci. 69(5), 567-580 (2001)

7. Bell NJ, Burget D, Howden CW, Wilkinson J, Hunt RH: Appropriate acid suppression for the management of gastro esophageal reflux disease. Digestion 51 (Suppl. 1), 59-67 (1992)

8. Biancani P, Sohn UD, Rich HG, Harnett KM, Behar J: Signal transduction pathways in esophageal and lower esophageal sphincter circular muscle. Am. J. Med. 103(5A), 23S-28S (1997)

9. Biswas K, Bandyopadhyay U, Chattopadhyay I, Varadaraj A, Ali E, Banerjee RK: A novel antioxidant and antiapoptotic role of omeprazole to block gastric ulcer through scavenging of hydroxyl radical. J. Bio. Chem. 278(13), 10993-11001 (2003)

10. Buege JA, Aust SD: Microsomal lipid peroxidation. Methods Enzymol. 52, 302-310 (1978)

11. Coman OA, Paunescu H, Ghita I, Coman L, Badaru A, Fulga I: Beta 3 adrenergic receptors: molecular, histological, functional and pharmacological approaches. Rom. J. Morphol. Embryol. 50(2), 169-179 (2009)

12. Hirschowitz BI: A critical analysis, with appropriate controls, of gastric and pepsin secretion in clinical esophagitis: Gastroenterology 101(5), 1149-1158 (1991)

13. Horinouchi T, Tanaka Y, Koike K: Beta 3-adrenoceptor mediated relaxation of guinea-pig gastric funds smooth muscle: cAMP-independent characteristics and a primary role of 4-aminopyridine-sensitive voltage-dependent $\mathrm{K}+(\mathrm{Kv})$ channels. Nihon Yakurigaku Zasshi 120(1), 109P-111P ( 2002)

14. Horn J: The proton-pump inhibitors: similarities and differences. Clin. Ther. 22(3), 266-280 (2000)

15. Kato S, Kitamura M, Korolkiewicz RP, Takeuchi K: Role of nitric oxide in regulation of gastric acid secretion in rats: effects of NO donors and NO synthase inhibitor. Br. J. Pharmacol. 123, 839-846 (1998)

16. Kobayashi T, Ohta Y, Inui K, Yoshino J, Nakazawa S: Protective effect of omeprazole against acute gastric mucosal lesions induced by compound 48/80, a mast cell degranulator, in rats. Pharmacological Research 46(1), 75-84 (2002)

17. Konturek SJ, Zayachkivska O, Havryluk XO, Brzozowski T, Sliwowski Z, Pawlik M, Konturek PC, Cześnikiewicz-Guzik M, Gzhegotsky MR, Pawlik WW: Protective influence of melatonin against acute oesophageal lesions involves prostaglandins, nitric oxide and sensory nerves. J. Physiol. Pharmacol. 58(2), 361-377 (2007)

18. Kvietys PR, Twohig B, Danzell J, Specian RD: Ethanol-induced injury to the rat gastric mucosa: Role of neutrophils and xanthine oxidase-derived radicals. Gastroenterology 98(4), 909-920 (1990)

19. Lahiri S, Singh P, Singh S, Rasheed N, Palit G, Pant KK: Melatonin protects against experimental reflux esophagitis. J. Pineal. Res. 46(2), 207-213 (2009)

20. Larsson H, Mattson H, Sundell G, Carlsson E: Animal pharmacodynamics of omeprazole. A survey of its pharmacological properties in vivo. Scand. J. Gastroenterol. 108 (suppl), 23-35 (1985)

21. Min YS, Lee SE, Hong ST, Kim HS, Choi BC, Sim SS, Whang WK, Sohn UD: The inhibitory effect of quercetin3-O-beta-D-glucuronopyranoside on gastritis and reflux esophagitis in rats. Korean J. Physiol. Pharmacol. 13(4), 295-300 (2009)

22. Modlin IM, Sachs G (2004): Acid related diseases: Biology and treatment. Lippincott Williams \& Wilkins, Philadelphia, USA 
23. Nakamura K, Ozawa Y, Furuta Y, Miyazaki H: Effects of sodium polyacrylate (PANa) on acute esophagitis by gastric juice in rats. Jpn. J. Pharmacol 32(3), 445-456 (1982)

24. Okabe S, Takinami Y, Iwata K, Yanagawa T: Mucosal protective effect of leminoprazole on reflux esophagitis induced in rats. Jpn. J. Pharmacol. 69(4), 317-323 (1995)

25. Paul A, Patel S, Sevak R, Goswami S, Santani D: Anti-ulcer and gastric inhibitory activity of Z 7114, a B3adrenoceptor agonist in rats. Indian J. Pharm. Sci. 63(5), 413-418 (2001)

26. Poplawski C, Sosnowski D, Szaflarska-Popławska A, Sarosiek J, McCallum R, Bartuzi Z: Role of bile acids, prostaglandins and COX inhibitors in chronic esophagitis in a mouse model. World J. Gastroenterol. 12(11), 1739-1742 (2006)

27. Sachs G, Shin JM, Besancon M, Prinz C: The continuing development of gastric acid pump inhibitors. Aliment. Pharmacol. Ther. 7 (Suppl. 1. 4-12), 29-31 (1993)

28. Sachs G: Proton pump inhibitors and acid-related diseases. Pharmacotherapy 17(1), 22-37 (1997)

29. Sarma DN, Banwait K, Basak A, Dimarino AJ, Rattan S: Inhibitory effect of 3-adrenoceptor agonist in lower esophageal sphincter smooth muscle: in vitro studies. J. Pharmacol. Exp. Therap. 304(1), 48-55 (2003)

30. Suzuki M, Mori M, Miura S, Suematsu M, Fukumura D, Kimura H, Ishii H: Omeprazole attenuates oxygenderived free radical production from human neutrophils. Free Radic. Biol. Med. 21(5), 727-731 (1996)

31. Vasina V, Abu-gharbieh E, Barbara G, De Giorgio R, Colucci R, Blandizzi C, Bernardini N, Croci T, Del Tacca M, de Ponti F: The $\beta_{3}$-adrenoceptor agonist SR58611A ameliorates experimental colitis in rats. Neurogastroenterol. Motil. 20(9), 1030-1041 (2008)

32. Watanabe T, Higuchi K, Tominaga K, Fujiwara Y, Arakawa T: Acid regulates inflammatory response in a rat model of induction of gastric ulcer recurrence by interleukin 1beta. Gut 48(6), 774-781 (2001)

33. Wetscher GJ, Perdikis G, Kretchmar DH, Stinson RG, Bagchi D, Redmond EJ, Adrian TE, Hinder RA: Esophagitis in Sprague-Dawley rats is mediated by free radicals. Dig. Dis. Sci. 40(6), 1297-1305 (1995)

34. Wolfe MM, Sachs G: Acid suppression: optimizing therapy for gastro duodenal ulcer healing, gastro-esophageal reflux disease, and stress-related erosive syndrome. Gastroenterology 118(2 Suppl. 1), S9-S31 (2000) 